International Journal of Business Management, Entrepreneurship and Innovation, Volume 2, Issue 2, 2020, PP 105-111, ISSN 2707-8027

[JCAB

\title{
Effect of Material Control Practices on Financial Performance of the Kenya Meat Commission in Kenya
}

\author{
Sigat Mohamud Aminazahra ${ }^{1}$, Chege Wambui Peris ${ }^{2}$ \\ ${ }^{1}$ Management Science Department, Kenyatta University (KU), Kenya, mishow70@gmail.com \\ ${ }^{2}$ Management Science Department, Kenyatta University (KU), Kenya
}

\begin{abstract}
Effective implementation of material control practices significantly improves the effectiveness of purchasing decisions and thus improved firm performance. To achieve this goal, material control practices must be fair, competitive and must control costs. However, in spite of the immense attention given to procurement practices and financial performance and the relationship that exist between the two constructs many organisations both private and public continue experience mixed performance. Anchored on the resource based theory the study sought to determine the effect of material control on financial performance of the Kenya meat commission. Descriptive Research Design was used. The study population comprised of Kenya Meat Commission headquarters in Athi River, Ladhies branch in Nairobi, Mombasa deport and the user department in Athi River. Since the population was small and of manageable sizes, a census study was done. Semi structured questionnaires was used to collect primary data. The respondent argued that the inventory quantities are very important in ensuring that these effective and efficiency in the operation of Kenya meat commission and ensuring that there is constant supply of meat to the users in Nairobi and its environment. It was evident that material planning control system (mean of 4.75) greatly affected the performance of Kenya meat commission. The finding on distribution material in Kenya meat commission as indicated by a mean of 4.00 presented that it greatly affected the financial performance of Kenya meat commission. The study concluded that the relationship between material control and financial performance of meat commission was positive and significant.
\end{abstract}

Key Words: Material Control Practices, Financial Performance, Kenya Meat Commission

DOI: $10.35942 / j b m e d . v 2 \mathrm{i} 2.121$

\section{Cite this Article:}

Aminazahra, S., \& Chege, P. (2020). Effect of Material Control Practices on Financial Performance of the Kenya Meat Commission in Kenya. International Journal of Business Management, Entrepreneurship and Innovation, 2(2), 105-111. https://doi.org/10.35942/jbmed.v2i2.121

\section{Introduction}

In Kenya the public procurement system has undergone numerous reforms since the mid-1980s to make it consistent with the global trade. It is worth noting that in 1997 the country procurement assessment review in Kenya which was reveals that there were very serious irregularities and drawbacks in the Kenyan public procurements systems by enhancing the centralities of the public procurements. This assessment laid down the on-the-ground the public procurement reforms which were later launched in 1998 whose pillars were accountability, transparency and value for money to the tenders (Rotich \& Okello, 2015). Segment of the Exchequer and the Audit act procurement public procurement in 2001 was aimed at organizing and governing the procurement in the public 
International Journal of Business Management, Entrepreneurship and Innovation, Volume 2, Issue 2, 2020, PP 105-111, ISSN 2707-8027

\section{[IJCAB}

sector and which lake Down the creation of public procurement directorate which oversees the public processes of procurement in Kenya. Public procurement complaints review and Appeals Board (PPCRAB) also was mandated to handle the tendering disputes.

However, an independent procurement review(IPR) in two thousand and five point that it was vital to further extend the reforms in procurement and have a legal sound framework through enactment of the Parliament. Forthwith the public procurement and disposal act (PPD) of 2005 was passed and it was established Public Procurement Oversight Authority (PPOA), Public Procurement Administrative Review Board(PPARB), Public Procurement Oversight Advisory Board (PPOAB) and repeated all other laws relating to public entities procurement by ensuring that our procurement was done by one body (Ayoyi \& Mukoswa, 2015). It is the work of public procurement authority to make the public procurement more efficient fair transparent that it is established five basic Pillars which guide the public procurement which includes transparent legal an institutional framework, standardize procurement and clear procedures and tender documents which are standard, measures of anti-corruption procurement measures which are independent and procurement staff with a proficient.

Onyango and Muturi (2016) operationalized tendering practices, supply regulation practices, ethical practices and operating practices. Kuloba (2016) measured procurement practices through tendering practices, supplier assessment practices and material control practices but the European Union (EU) indicated that procurement practices to be adopted by member countries should be open practices and restricted practices. Mizuno (2014) operationalized procurement practices into selection of suppliers to be invited to tender, request for and submission of tenders, technical evaluation, negotiation and award of contract and delivery, inspections, and payment. On the other hand, Amann and Essig (2015) observed that in any organization there are standard procurement practices that are always defined relating to procurement cost levels, purchase requisitions ethical codes (including gifts and inducements, declaration of interest, supplier interaction and confidentiality), standard agreements, value for money, tendering, E procurement and Ad hoc purchases. While Jeptepkeny (2015) measured procurement practices into specification definition, bid invitation, bid evaluation and contract negotiation.

The Kenya Meat Commission (KMC) was formed in 1950 through an act of parliament with an objective of providing a ready market for livestock farmer and providing high quality meat and meats products to customers. It is a public institutions and by far the oldest and the most experienced meat processors in Kenya and the larger East Africans regions. KMC is a fully integrated meat processor whose strengths lies in the unrivalled efficiencies of its meat processing plants along with its ability to processes high volumes of qualities meat in line with consumer's taste and preference (Kingei, 2015). The parastatal has fixed operating costs of Sh20 million per month including Sh10 million for salaries and Sh4 million for electricity. Due to financial challenges the commission was shut down in 1991. In 2006, KMC was re-opened with the objective of promoting the meat industry in Kenya, both domestic and for export. However, since it's re-opening in 2006. KMC has been struggling to meet its costs and is currently facing bankruptcy and its racing against time to stay afloat. Cash-strapped Kenya Meat Commission (KMC) sold products worth Sh127.5 million in the nine months (June 2018 to March 2019) as it continues to operate below capacity. Despite the government having pumped in over Sh4.1 billion in 13 years since 2006 with Sh2.3 billion of it being for development, the cash-strapped meat processor runs on archaic machines that are manually operated, pushing up labor costs and has 
International Journal of Business Management, Entrepreneurship and Innovation, Volume 2, Issue 2, 2020, PP 105-111, ISSN 2707-8027

[IJCAB

consistently made losses over the years. During the financial year 2018, KMC posted a net loss of Sh228.1 million, a slight improvement from the Sh309.2 million loss made a year earlier (2017). Its debts stand at Sh1.1 billion, which include livestock farmers' dues of Sh254.4 million and outstanding payroll deductions totaling Sh144 million. In an attempt to raise funds KMC formed a task force to spearhead collection of debts as it moves to settle liabilities. It is also noted that the state-owned meat processor does not operate optimally and only slaughters 200 cattle per week which is equivalent to a day's capacity. This fact may be attributed to inability of the abattoir to attract livestock from suppliers due to failure to pay livestock farmers for their deliveries which has disrupted its supplies.

\section{Statement of the Problem}

Over the year's scholars and consultants have sought to establish what really affects the financial performance of an organisation. Many factors such as organisation culture, resource availability, efficiency and effectiveness of the management team, management strategies, employee motivation, knowledge management among others (Kingei, 2015). Despite the significant contribution of Kenya Meat Commission in Kenyan economy, scanty studies have been done to evaluate the contribution of various variables such as procurement practices on its financial performance. The study therefore intended to fill the identified gaps by determining the effect of procurement practices on financial performance of the Kenya Meat Commission.

\section{Research Objective}

i. To assess the effect of material control practices on financial performance of the Kenya meat commission

\section{Theoretical Literature Review}

Resource-Based View Theory was designed by Grant in 1991 and earlier supported by Hill (1989). The theory supposed that the extensive analysis and the operating capabilities and competencies of the firm a based on the firm's capabilities and Resources. The theories based on the capability and the concept to the firm can use to slice the economic resources of the company and the view of the company to use the collection of its cover abilities and employees within the firm. This theory explains the material control and how they will affect the financial position of Kenya meat commission.

\section{Empirical Review}

Oyebamiji (2018) examined the effect of materials managements on the performances of manufacturing industry with particulars reference to the selected cement industry. 30 respondents were selected for the study. Structured questionnaires and a personal interview were used to collect data. Data analysis was conducted with the aids of multiple regression analysis. The result revealed that materials management dimensions jointly contributes significantly to firm performances. The findings further revealed that materials inventory, materials procurements and inter-departmental collaborations have an insignificant effect on firm performances. Ibegbulem and Okorie (2015) study on handling of organizations material management. The study found that the organizations can handle the problems which are connected to effective material management to increase the profitability in Nigeria. Study revealed that the material management in Nigeria was used for the purposes of increasing profitability for the majority of the companies to ensure storage facilities are adequately use without interruption and production processes among other things are kept 
International Journal of Business Management, Entrepreneurship and Innovation, Volume 2, Issue 2, 2020, PP 105-111, ISSN 2707-8027

\section{[IJCAB}

intact. Study recommended that there should be a good record system connected to material for the purposes of good operations of the organization which ensures productivity and training of employees to acquire better knowledge and skills for the work of the organization and benefits of the shareholders in general.

Keitny, Wanyoike and Ricu (2014) sought to assess the role of materials managements on organizational performances of the New Kenya Cooperative Creameries, Eldoret, Kenya. The study targeted 49 employees from different departments including productions, purchasing, quality Controls, Warehouse/stores, Human Resources Developments, Finances and audits and physical Distributions departments. Data was collected through a structured questionnaires and analyses through descriptive statistics. The findings showed that there were significant increases in organizational performances as a results of inventory controls systems involvement. Further, results showed that lead time was highly significant to organizational performances through acquiring and delivering the needed materials within the shortest time possible.

Ondiek and Odera (2012) studies the recognition of manufacturing companies in Kenya by giving to material management and the benefits of adopting good material management practices. The study found that there's a long-term success and the survival of these companies who depend on where management of the material costs. The study did a survey of large and medium manufacturing companies which were based in Kenya Nairobi. Sampling technique was used which was stratified and selected 55 companies while data was collected using questionnaires which were open-ended questionnaires. Data was analyzed through the description measures. $23 \%$ of these companies found to have recognized material management is the head in charge reported directly to the chief executive. The study found that Kenyan manufacturing firms were not practicing professionalism in management and Material Handling going to the amount increasing or resources that were committed to material and related activities.

\section{Research Methodology}

This study adopted descriptive research design. According to Mugenda and Mugenda (2003) descriptive research is a research that attempts to gather facts from a population so as to establish the existing status of the respondents in regards to the variables. The study utilized primary data that was collected using questionnaires from the Kenya Meat Commission staff members. The study targeted Kenya Meat Commission Headquarters in Nairobi, Ladhies Procurement department, Mombasa Deport and the user department in Athi river branch. 13 employees in the Ladhies procurement department, 21 employees from Athi River Headquarters procurement department, 11 employees from Mombasa Depot, and 26 employees from user departments in Athi River in Machakos County were the respondents. Since the population was small and of manageable size the researcher used a census. Semi structured questionnaires were used to collect the primary data. The tool contained two sections. Drop and pick methods of using the questionnaire was used to administer the questionnaire in this study which allowed the respondents to have an adequate time to seek and see the responses according to the check result. The researcher booked the appointment with the respondents prior to the data collection and then dropped the questionnaires to make any necessary clarification needed.

Data collected from the field was first edited, cleaned and evaluated to establish accuracy, completeness, consistency and usefulness. Once data was cleaned it was coded and fed in to the analysis software. Data was analysed statistically using Statistical Package for Social Science 
International Journal of Business Management, Entrepreneurship and Innovation, Volume 2, Issue 2, 2020, PP 105-111, ISSN 2707-8027

[ICAB

(SPSS) version 23. In addition to descriptive statistics, inferential analysis was conducted using multiple regression model to determine the effect of procurement practices on performance of KMC.

\section{Research Findings and Discussions}

Regression analysis presented the relationship between dependent and independent variable. The dependent variable was performance of Kenya meat commission on the independent variable was material control procedures. The model summary was used to present the correlation coefficient and the coefficient of determination. Correlation coefficient measures the strength and nature of the relationship between variables while the coefficient of determination measures the extent to which the independent variable will determine the changes in the dependent variable. The results were presented table 1 .

Table 1: Model Summary

\begin{tabular}{|l|l|l|l|l|}
\hline Model & R & R Square & Adjusted R Square & Std. Error of the Estimate \\
\hline 1 & $.776^{\mathrm{a}}$ & .602 & .516 & .23415 \\
\hline
\end{tabular}

Source: Research Data (2020)

Material control contributed to $51.6 \%$ changes in the financial performance of Kenya meat commission (Adjusted R-squared of 51.6\%). It is true that $48.4 \%$ all the changes of financial performance of Kenya meat commission was determined by other factors not considered in the study. Relationship between the independent variable (material control) and dependent variable (financial performance of Kenya meat commission) was found to be positive and strong (correlation coefficient $=\mathrm{R}=.776$ ).

\section{Table 2: Regression Coefficients}

\begin{tabular}{|llllll|}
\hline & \multicolumn{2}{l}{$\begin{array}{l}\text { Unstandardized } \\
\text { Coefficients }\end{array}$} & \multicolumn{2}{l|}{$\begin{array}{c}\text { Standardized } \\
\text { Coefficients }\end{array}$} & \\
Model & B & Std. Error & Beta & T & Sig. \\
(Constant) & 13.308 & 2.243 & & 1.236 & 1.215 \\
Material Control & 0.999 & 0.215 & 0.231 & 3.112 & .001 \\
\hline
\end{tabular}

Source: Research Data (2020)

The model used was; $\mathbf{Y}=\boldsymbol{\beta}_{\mathbf{0}}+\boldsymbol{\beta}_{1} \mathbf{X}_{\mathbf{1}}+\boldsymbol{\varepsilon}$ therefore: $\mathrm{Y}=13.308+0.999 \mathrm{X}_{3}+\boldsymbol{\varepsilon}$. The regression coefficients present that holding factors considered in the model constant (material control) changes in the financial performance of Kenya meat commission would be 13.308 units $\left(\beta_{0}=\right.$ 13.308). The results on the relationship between material control and financial performance of meat Commission was positive and significant $\left(\beta_{3}=.999, \mathrm{P}=.001\right)$. The results also indicate that a unit change in the material control would result to 0.999 units' changes in the financial performance of Kenya meat commission. The findings support Ondiek and Odera (2012) findings that material control positively and significantly affects financial performance. The study also agrees with Keitny, Wanyoike and Ricu (2014) material control affects greatly the organizational performance. 
International Journal of Business Management, Entrepreneurship and Innovation, Volume 2, Issue 2, 2020, PP 105-111, ISSN 2707-8027

[IJCAB

\section{Conclusions and Recommendations}

The study concluded that the relationship between material control and financial performance of meat Commission was positive and significant. The study also concluded that a unit change in the material control would result to positive units' changes in the financial performance of Kenya meat commission. The study concluded that inventory quantity levels, inventory control systems, material handling and physical distribution of resources were significant contributors to financial performance of Kenya Meat Commission. Based on the conclusions of the study, the following recommendations were made. The study recommended that tendering process should consider open method of tendering which is fair to all. The researcher recommended that the management of Kenya meat commission should ensure fairness in tendering process by having an open and clear systems. This will ensure that there is competitiveness in the tendering process in Kenya Meat Commission. The research also recommends that the Government should ensure that process of material control and supplier assessment process in Kenya meat commission is clear and that there is a unit responsible for each step.

\section{REFERENCES}

Aberi, M. (2012). The relationship between organizational culture and the performance of secondary schools in Gucha district (Unpublished Doctoral dissertation), University of Nairobi, Kenya

Albano, G. L., Cesi, B., \& Iozzi, A. (2017). Public procurement with unverifiable quality: The case for discriminatory competitive procedures. Journal of Public Economics, 145, 14-26.

Amann, M., \& Essig, M. (2015). Public procurement of innovation: empirical evidence from EU public authorities on barriers for the promotion of innovation. Innovation: The European Journal of Social Science Research, 28(3), 282-292.

Flynn, A., \& Davis, P. (2014). Theory in public procurement research. Journal of public procurement, 14(2), 139-180.

Hoque, Z. (2014). 20 years of studies on the balanced scorecard: trends, accomplishments, gaps and opportunities for future research. The British accounting review, 46(1), 33-59.

Mizuno, E. (2014). Overview of wind energy policy and development in Japan. Renewable and sustainable energy reviews, 40, 999-1018.

Mogikoyo, L. K., Magutu, P. O., \& Dolo, A. B. (2017). The Link between Supplier Evaluation Attributes and Supply Chain Performance of Government Owned Entities: Perspectives from Commercial State Corporations in Kenya. Noble International Journal of Economics and Financial Research, 2(1), 1-20.

Mugenda, O. M., \& Mugenda, A. G. (2003). Research methods. Quantitative and qualitative approaches, 46-48.

Mutai, D. K., \& Chirchir, M. K. (2015). Impact of Procurement Policies and Procedures on Supply Chain Performance of Commercial Banks in Kenya. International journal of education and research, 5(3), 73-74.

Mwangi, M. (2014). Supplier relationship management and operational performance of sugar firms in Kenya. (Doctoral dissertation, School of Business, University of Nairobi).

Nguyen, H. (2013). Supplier performance evaluation documentation and process in the textile and garment manufacturing industry. Company case: X.

Niven, P. R. (2011). Balanced scorecard: Step-by-step for government and nonprofit agencies. New York: John Wiley \& Sons. 
International Journal of Business Management, Entrepreneurship and Innovation, Volume 2, Issue 2, 2020, PP 105-111, ISSN 2707-8027

[IJCAB

Northcott, D., \& Ma'amora Taulapapa, T. (2012). Using the balanced scorecard to manage performance in public sector organizations: Issues and challenges. International Journal of Public Sector Management, 25(3), 166-191.

Oballah, D., Waiganjo, E., \& Wachiuri, W. E. (2015). Effect of inventory management practices on Organizational performance in Public health institutions in Kenya: A case study of Kenyatta national hospital. International journal of education and research, 3(3), 703-714.

Ondiek, G. O., \& Odera, O. (2012). Assessment of materials management in Kenyan manufacturing firms. Journal of business studies quarterly, 3(3), 40.

Oyebamiji, F.F. (2018) Materials Management and its Effect on the Performance of Manufacturing Sector: Evidence from Nigerian Cement Industry. South Asian Journal of Social Studies and Economics

Rotich, G. K., \& Okello, B. (2015). Analysis of use of e-procurement on performance of the procurement functions of County Governments in Kenya. International Journal of Economics, Commerce and Management, 3(6), 1381-1398.

Saussier, S., \& Tirole, J. (2015). Strengthening the efficiency of public procurement. Notes $d u$ conseil d'analyse économique, (3), 1-12.

Schroeder, R., Rungtusanatham, M. J., \& Goldstein, S. (2012). Operations management in the supply chain. (UK) McGraw-Hill Higher Education.

Scott, P. (1995). The meanings of mass higher education. UK: McGraw-Hill Education

Seo, J. S., Seo, W. C., \& Ock, Y. S. (2014). A Study on the Improvement of Aquaculture Certification System to Meet Greater Retailers Supplier Assessment Requirement. The Journal of Fisheries Business Administration, 45(1), 33-47.

Singh, S., Darwish, T. K., \& Potočnik, K. (2016). Measuring organizational performance: A case for subjective measures. British Journal of Management, 27(1), 214-224.

Upadhaya, B., Munir, R., \& Blount, Y. (2014). Association between Performance Measurement Systems and Organisational Effectiveness. International Journal of Operations \& Production Management, 34(7), 2-2.

Uttam, K., \& Roos, C. L. L. (2015). Competitive dialogue procedure for sustainable public procurement. Journal of Cleaner Production, 86, 403-416.

Wachiuri, E. W. (2019). Influence of Supplier Evaluation Criteria on the Performance of State Corporations in Kenya (Doctoral dissertation, JKUAT-COHRED).

This is an open-access article published and distributed under the terms and conditions of (c) (†) (8)

the Creative Commons Attribution 4.0 International License of United States unless otherwise stated. Access, citation and distribution of this article is allowed with full recognition of the authors and the source.

Authors seeking to publish with an Internationally Peer Reviewed Journals should consider https://www.ijcab.org/ by writing to the Editor at editor@ijcab.org or submitting online at https://journals.ijcab.org/journals/index.php. The articles must be quality and meet originality test. 